\title{
Analysis of $z$ ntA gene in environmental Escherichia coli and additional implications on its role in zinc translocation
}

\author{
Anandhan Vidhyaparkavi ${ }^{1} \cdot$ Jabez Osborne $^{1} \cdot$ Subramanian Babu $^{1}$
}

Received: 19 October 2016/Accepted: 8 January 2017/Published online: 8 April 2017

(c) The Author(s) 2017. This article is an open access publication

\begin{abstract}
Escherichia coli strains from sewage sample were screened for the presence and expression of heavy metal-translocating zntA gene by PCR and RT-PCR analysis with type culture of K-12 as standard strain. The strain which showed high level of gene expression (SBVP1) was chosen to further study the growth and heavy metal translocation. This superior strain was grown in the presence of $\mathrm{ZnSO}_{4}, \mathrm{~Pb}\left(\mathrm{CH}_{3} \mathrm{COO}\right)_{2}$ and mixture of $\mathrm{ZnSO}_{4}$, $\mathrm{Pb}\left(\mathrm{CH}_{3} \mathrm{COO}\right)_{2}$ metal salts and the growth was observed at different time points. The cell pellet fraction was found to have more of zinc than lead as determined by atomic absorption spectroscopy indicating the translocation of these metals from media to the cells. However, the intracellular translocation of zinc is affected by the presence of lead in the media. Expression of the $z n t \mathrm{~A}$ gene in bacteria grown in the presence of $\mathrm{ZnSO}_{4}$ was also studied and the molecular analysis results correlate with spectroscopic observations.
\end{abstract}

Keywords E. coli $\cdot$ Lead $\cdot$ Translocation $\cdot$ Zinc $\cdot$ znt A gene

\section{Introduction}

Heavy metal pollution causes many genetic problems and has been a great threat around the world. The need for the development of efficient and economic ways for the degradation of these heavy metals is of top priority in the attempts to clean our environment. Use of microorganisms

Subramanian Babu

babu.s@vit.ac.in

1 School of Bio Sciences and Technology, VIT University, Vellore 632014, India which have metal-resistant capacity in metal polluted areas reduces the metal bioavailability and helps in the bioremediation of the soils ( $\mathrm{Ji}$ and Silver 1995). These microorganisms possess different types of metal-resistant mechanisms like intra- and extra-cellular metal sequestration, metal efflux pumps, metal reduction and production of metal cheaters (Nies 1992, 1999; Rosen 1996). In the postgenomic era, molecular biological approaches based on genome sequences help to study the different genes and proteins that play a role in the degradation of these heavy metals.

E. coli, the most common bacterium found in contaminated soil is known to have many metal degradative properties. The first $\mathrm{Zn}$ (II)-translocating P-type ATPase has been identified as the product of $z n t \mathrm{~A}$, a potential gene identified after sequencing of the E. coli genome (Rensing et al. 1997). This soft metal-translocating P1-type ATPase confers resistance to $\mathrm{Pb}(\mathrm{II}), \mathrm{Cd}(\mathrm{II})$, and $\mathrm{Zn}$ (II).

Although the functional characterization of $z n t \mathrm{~A}$ gene in E. coli by gene disruption (Rensing et al. 1997; Wang et al. 2012) has been reported, functional analysis in the native $E$. coli isolates of the sewage samples with the aim to screen and identify an efficient bioremediating strain has not been reported so far. In this study, we report the screening and functional characterization of $E$. coli isolates from sewage sample. Several genes and proteins including $z n t \mathrm{~A}$ have been reported to play a role in zinc influx and efflux machinery of the bacteria. However, the discrete behavior of the individual genes/proteins under specific conditions, especially when zinc is present along with other heavy metals in the growth media is not studied. We describe here the results of our attempt to study the translocation of zinc when it is present alone as well as in combination with lead in the growth environment of E. coli. 


\section{Materials and methods}

\section{E. coli strains}

Sewage water sample from the sewage treatment plant at VIT University, Vellore, India, was used for the isolation of E. coli. Samples were serially diluted and plated on MacConkey and EMB agar. Isolates were subcultured and maintained in EMB agar. E. coli type culture strain K-12 (MTCC 1302) was obtained from Microbial Type Culture Collection, Institute of Microbial Technology, Chandigarh, India. Standard biochemical tests viz, Gram's staining, methyl red, Voges-Proskauer, indole, citrate utilization, triple sugar iron were performed as per the standard procedures.

\section{Isolation of gDNA from $E$. coli strains}

Genomic DNA from E. coli isolates as well as the type culture was isolated by $\mathrm{CTAB} / \mathrm{NaCl}$ procedure. Briefly, the bacterial cells were pelleted down by centrifuging at $8000 \times g$ for $5 \mathrm{~min}$. The pellet was resuspended in $567 \mu \mathrm{L}$ of TE buffer, $\mathrm{pH} 7.5$ by repeated pipetting. About $30 \mu \mathrm{L}$ of $10 \% \mathrm{SDS}$ and $3 \mu \mathrm{L}$ of proteinase $\mathrm{K}$ stock $(10 \mathrm{mg} / \mathrm{mL})$ were added. The suspension was mixed by inverting and incubated at $37{ }^{\circ} \mathrm{C}$ for an hour. About $100 \mu \mathrm{L}$ of $5 \mathrm{M} \mathrm{NaCl}$ was added and mixed by inverting. This was followed by addition of $80 \mu \mathrm{L}$ of $\mathrm{CTAB} / \mathrm{NaCl}$ solution $(10 \% \mathrm{CTAB}$, $0.7 \mathrm{M} \mathrm{NaCl}$ ). Tubes were incubated at $65^{\circ} \mathrm{C}$ for $10 \mathrm{~min}$ and the contents were extracted with equal volume of chloroform:isoamyl alcohol. After centrifugation at $12,000 \times g$ for $5 \mathrm{~min}$, the aqueous layer was transferred to fresh tube and 0.6 volume of ice-cold isopropanol was added. DNA was precipitated by centrifuging at $10,000 \times g$ for $5 \mathrm{~min}$ and the pellet was washed with $70 \%$ ethanol, air dried and suspended in $20 \mu \mathrm{L}$ of TE buffer.

\section{PCR and RT-PCR analysis of zntA gene}

The sequence of $z n t \mathrm{~A}$ gene (E. coli $\mathrm{K}-12$ sub strain MG1665 (NCBI GenomeID, NP_000913.2) was obtained from the NCBI microbial genome database and Primer3 online tool was used to design the PCR primers (forward$5^{\prime}$ GCAGGCGTGAATCAGGTGCT $3^{\prime}$ and reverse- $-5^{\prime}$ GCGCCCGCTGTGATTCGGCG $3^{\prime}$ ). Primers were synthesized at Bioserve Biotechnologies India Private Limited, Hyderabad, India.

PCR reaction mixture consisted of $100 \mathrm{ng}$ DNA, $0.2 \mu \mathrm{M}$ each primer, $50 \mathrm{mM} \mathrm{KCl}, 10 \mathrm{mM}$ Tris $\mathrm{Cl}(\mathrm{pH} 8.3)$, $1.5 \mathrm{mM} \mathrm{MgCl}_{2}, 200 \mathrm{mM}$ of each deoxynucleotide triphosphates and $1 \mathrm{U}$ Taq polymerase. PCR was carried out using following conditions: initial denaturation at
$94{ }^{\circ} \mathrm{C}$ for $2 \mathrm{~min}$; 30 cycles of denaturation at $94{ }^{\circ} \mathrm{C}$ for $1 \mathrm{~min}$, annealing at $52{ }^{\circ} \mathrm{C}$ for $1 \mathrm{~min}$, extension at $72{ }^{\circ} \mathrm{C}$ for $1 \mathrm{~min}$ and a final extension period of $10 \mathrm{~min}$ at $72^{\circ} \mathrm{C}$ ) and analyzed in $1 \%$ agarose gel.

Total RNA was isolated from bacterial cell pellet obtained from overnight cultures of the isolates grown in nutrient broth supplemented with $5 \%$ v/v sewage water (original source from which isolates were collected) using RaFlex Kit (Genei, Bangalore, India) as per kit instructions. First-strand cDNA synthesis was carried out with 20 ng RNA, AMV reverse transcriptase and reverse primer using cDNA Synthesis Kit (Genei, Bangalore, India) as per the kit instructions. The reaction mixture was incubated at $42{ }^{\circ} \mathrm{C}$ for $1 \mathrm{~h}$ and terminated at $70{ }^{\circ} \mathrm{C}$ for $10 \mathrm{~min}$ followed by chilling on ice. PCR was carried out using $5 \mu$ of cDNA (synthesized from $20 \mathrm{ng}$ RNA), $2 \mathrm{U}$ Taq polymerase, $200 \mu \mathrm{M}$ each dNTP and $1.5 \mathrm{mM} \mathrm{MgCl}_{2}$. Primers were used at $0.2 \mu \mathrm{M}$ final concentration. Amplification was done with initial denaturation at $95{ }^{\circ} \mathrm{C}$ for $2 \mathrm{~min}$ followed by 30 cycles of $95{ }^{\circ} \mathrm{C}$ for $1 \mathrm{~min}, 52{ }^{\circ} \mathrm{C}$ for $1 \mathrm{~min}$ and $72{ }^{\circ} \mathrm{C}$ for $1 \mathrm{~min}$. This was followed by final extension step of $72{ }^{\circ} \mathrm{C}$ for $7 \mathrm{~min}$. The PCR products were analyzed in $1 \%$ agarose gel stained with ethidium bromide.

\section{Evaluation of $\mathrm{E}$. coli for $\mathrm{Zn}$ and $\mathrm{Pb}$ tolerance}

The E. coli isolate which showed high expression of zntA gene was used in the study to determine the minimum inhibitory concentration (MIC) of $\mathrm{Zn}$ and $\mathrm{Pb}$ salts. The isolate was grown in liquid media containing varying concentrations of $\mathrm{ZnSO}_{4}(0-5 \mathrm{mM})$ and $\mathrm{Pb}\left(\mathrm{CH}_{3} \mathrm{COO}\right)_{2}$ (0-5 mM) separately. Heavy metal salt containing media were inoculated with overnight cultures of the isolate and incubated in environmental shaker at $37{ }^{\circ} \mathrm{C}$ for 2 days. The growth was measured by recording the OD at $610 \mathrm{~nm}$. The E. coli isolate was cultured in liquid media containing MIC of $\mathrm{Zn}$ and $\mathrm{Pb}$ salt (3.5 and $4 \mathrm{mM}$, respectively) separately as well as in combination. The cultures were allowed to grow for 5 days and the OD at $610 \mathrm{~nm}$ was recorded at a time interval of $24 \mathrm{~h}$.

\section{Atomic absorption spectroscopy (AAS) analysis of heavy metals}

The sewage water used to isolate $E$. coli was analyzed for heavy metals like zinc $(\mathrm{Zn})$, lead $(\mathrm{Pb})$, copper $(\mathrm{Cu})$ and mercury $(\mathrm{Hg})$ at the AAS facility of technology business incubator, VIT University, Vellore, India.

E. coli cultures grown in media containing MIC of $\mathrm{Zn}$ and $\mathrm{Pb}$ salt separately as well as in combination were transferred to $10 \mathrm{~mL}$ tubes and centrifuged at $5000 \mathrm{rpm}$ for $10 \mathrm{~min}$. The supernatant was separated. The cell pellet was acid digested using concentrated $\mathrm{HCl}$ (Guven and Akinci 
2011) by incubating at $90{ }^{\circ} \mathrm{C}$ for $2 \mathrm{~h}$. The digested cell extract was filtered through Whatman No. 1 filter paper, diluted and used for AAS analysis. Based on the mean absorbance, concentration of $\mathrm{Zn}$ and $\mathrm{Pb}$ was determined by comparing with mean absorbance of the standard $\mathrm{Zn}$ and $\mathrm{Pb}$.

\section{RT-PCR analysis of $\mathrm{ZnSO}_{4}$-induced $z$ nt $\mathrm{A}$ gene expression}

Total RNA was isolated from E. coli isolate grown in the MIC of $\mathrm{ZnSO}_{4}$ and RT-PCR analysis of zntA gene was performed as described earlier. The same isolate grown in media without $\mathrm{ZnSO}_{4}$ was used for comparison.

\section{Results and discussion}

The E. coli zinc homeostasis is known to be regulated by networking of influx and efflux pumping systems (Hantke 2001; Blencowe and Morby 2003). At high zinc concentration, zntA, a P-type transporter of efflux system is upregulated (Rensing et al. 1997; Outten et al. 1999). In addition, zit $\mathrm{B}$, a cation diffusion facilitator (Grass et al. 2001; Lee et al. 2002) and many other transporters are known to play a role in translocation of zinc ions (Grass et al. 2005; Hantke 2005; Wei and Fu 2005). The discrete function of each transporter/facilitator of the influx and efflux system is studied to some extent. Nevertheless, their functions under specific conditions, specifically when zinc is present along with high concentration of other heavy metals are largely unknown. Our study described here represents a step forward in this area of research demonstrating the translocation of zinc when it is present alone as well as in combination with lead in the growth environment of E. coli.

The sewage sample used in the study contained 2.90, $1.04,0.08$ and $0.50 \mathrm{mg} / \mathrm{L}$ of $\mathrm{Hg}, \mathrm{Zn}, \mathrm{Pb}$ and $\mathrm{Cu}$, respectively (Table 1). E. coli strains were isolated and characterized based on cultural and biochemical methods as described. The strains were designated as SBVP1, SBVP2,
SBVP3 and SBVP4. Primers for the amplification of $z n t \mathrm{~A}$ gene were designed based on the gene sequence of $E$. coli K-12 substr. MG1655. All the four strains from sewage sample as well as the K-12 type culture showed amplification of the zntA gene in PCR done with genomic DNA (Fig. 1a). However, RT-PCR with total RNA obtained from these strains showed expression of the gene in sewage-derived strains only (Fig. 1b). Among these strains, SBVP1 which showed higher expression was chosen for further study and grown in varying concentrations $(0-5 \mathrm{mM})$ of $\mathrm{Zn}$ and $\mathrm{Pb}$ salts. $\mathrm{ZnSO}_{4}$ of $3.5 \mathrm{mM}$ and $\mathrm{Pb}(\mathrm{CH} 3 \mathrm{COO})_{2}$ of $4.0 \mathrm{mM}$ were found to be the concentrations after which further increase in concentration resulted in reduced growth of bacteria. The strain SBVP1 was further grown in media containing the optimized concentrations of $\mathrm{Zn}$ and $\mathrm{Pb}$ salts separately as well as in combination. The results of growth of this strain in this experiment are shown in Fig. 2. The growth was found to be slow but steady in media containing $3.5 \mathrm{mM} \mathrm{ZnSO}_{4}$ until observed $(144 \mathrm{~h})$. In contrast, the growth of bacteria in $\mathrm{Pb}$ salt containing media was high initially but with further flat growth level as compared to steep raise in $\mathrm{Zn}$ containing media. When the heavy metal salts were used in combination, a similar flat growth rate was observed. The result of this experiment indicate that the E. coli strain although tolerates $\mathrm{Zn}$ by possible translocation, the growth is affected by the presence of $\mathrm{Pb}$ salt. To confirm these observations, $\mathrm{Zn}$ and $\mathrm{Pb}$ were estimated in the bacterial cell pellet extract and expressed as $\mathrm{mM}$ (Table 2). Cell pellet extract of SBPV1 contained $1.039 \mathrm{mM} \mathrm{Zn}$ in $\mathrm{ZnSO}_{4}$ containing media compared to $0.308 \mathrm{mM}$ in media containing $\mathrm{Zn}$ and $\mathrm{Pb}$ salts. The result of this estimation supports the observation made on growth of bacteria. Wang et al. (2012) proposed that the dramatic increase in intracellular free $\mathrm{Zn}$ is caused by sudden increase in $\mathrm{Zn}$ influx due to increased extracellular concentration coupled with lack of sufficient intracellular ligands to rapidly sequester and buffer all these excess zinc.

The concentration of $\mathrm{Pb}$ in cell pellet extract obtained from $\mathrm{Pb}+\mathrm{Zn}$ containing media was higher $(0.140 \mathrm{mM})$
Table 1 Analysis of heavy metals in sewage sample used in the study

\begin{tabular}{|c|c|c|c|}
\hline Heavy metal & Standard/sample & Concentration (mg/L) & Mean absorbance \\
\hline \multirow[t]{2}{*}{$\mathrm{Hg}$} & Standard $\mathrm{Hg}$ & 15.00 & 0.0235 \\
\hline & Sewage sample & 2.900 & 0.0045 \\
\hline \multirow[t]{2}{*}{$\mathrm{Zn}$} & Standard Zn & 15.00 & 0.9622 \\
\hline & Sewage sample & 1.038 & 0.0669 \\
\hline \multirow[t]{2}{*}{$\mathrm{Pb}$} & Standard $\mathrm{Pb}$ & 15.00 & 0.0703 \\
\hline & Sewage sample & 0.080 & 0.0004 \\
\hline \multirow[t]{2}{*}{$\mathrm{Cu}$} & Standard $\mathrm{Cu}$ & 15.00 & 0.3299 \\
\hline & Sewage sample & 0.502 & 0.0110 \\
\hline
\end{tabular}




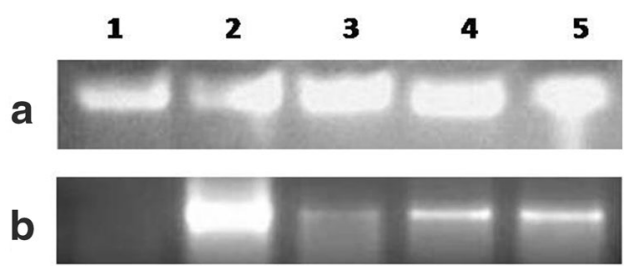

Fig. 1 Molecular analysis of zntA gene in E. coli strains. a PCR analysis of $z n t \mathrm{~A}$ using genomic DNA isolated from $E$. coli strains; b RT-PCR analysis of $z n t \mathrm{~A}$ using total RNA obtained from $E$. coli strains. Lanes $1 \mathrm{~K}-12$, 2 SBVP1, 3 SBVP2, 4 SBVP3, 5 SBVP4

a Growth of E. coli SBVP1 in media containing $3.5 \mathrm{mM} \mathrm{ZnSO} 4$

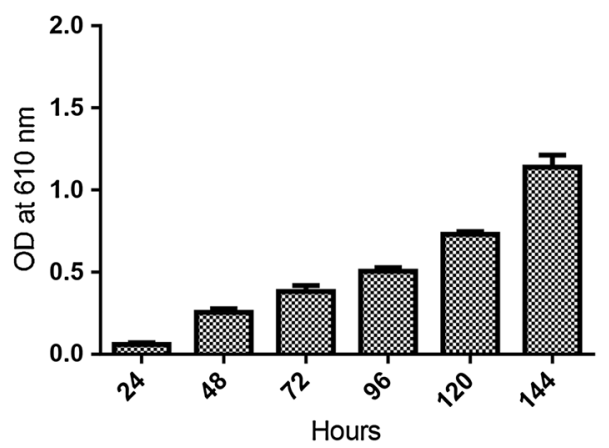

b Growth of $E$. coli SBVP1 in media containing $4.0 \mathrm{mM} \mathrm{Pb}\left(\mathrm{CH}_{3} \mathrm{COO}\right)_{2}$

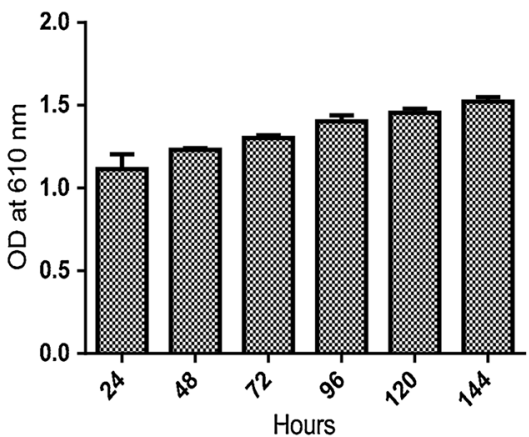

C Growth of E. coli SBVP1 in media containing $3.5 \mathrm{mM} \mathrm{ZnSO}_{4}$ $+4.0 \mathrm{mM} \mathrm{Pb}\left(\mathrm{CH}_{3} \mathrm{COO}\right)_{2}$

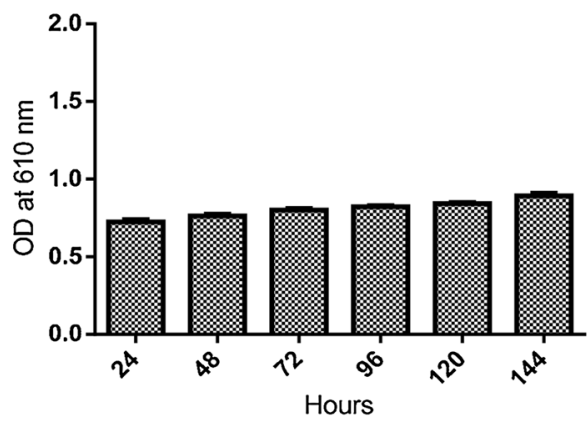

Fig. 2 Growth of E. coli SBVP1 in media containing $\mathrm{Zn}$ and $\mathrm{Pb}$ salts separately and in combination when compared to the concentration in cell pellet extract obtained from media with $\mathrm{Pb}$ salt alone $(0.038 \mathrm{mM})$. This observation pushes us to an understanding that translocation of $\mathrm{Pb}$ require the presence of $\mathrm{Zn}$. In other words, presence of $\mathrm{Zn}$ would have triggered $z n t \mathrm{~A}$ gene-mediated translocation of $\mathrm{Pb}$. In addition to $\mathrm{Zn}$, znt $\mathrm{A}$ gene is already known to translocate $\mathrm{Pb}$ and $\mathrm{Cd}$ (Silver 1996). Moreover, the much higher accumulation of $\mathrm{Zn}$ in cells as observed in media containing $\mathrm{Zn}$ alone was not the scenario when the media contained $\mathrm{Zn}$ and $\mathrm{Pb}$. This observation made us to analyze the expression of $z n t \mathrm{~A}$ gene in the cells grown in $\mathrm{ZnSO}_{4}$ containing media compared to media without any heavy metal salts. The expression of zntA was higher in the presence of $\mathrm{ZnSO}_{4}$ (Fig. 3). The amplified DNA was eluted form the gel and sequenced to confirm the results. The sequence was submitted to GenBank with an Accession no. of KC598125.1.

Gene knock-out studies have shown the elimination of znt A resulting in high accumulation of $\mathrm{Zn}$ (II) in the cells (Rensing et al. 1997). Furthermore, deletion of $z i t \mathrm{~B}$ and $z n t \mathrm{~A}$ has proved $z n t \mathrm{~A}$ as primary transporter to combat high zinc concentrations (Grass et al. 2001). Wang et al. (2012) employed genetically encoded fluorescent zinc sensor to monitor the intracellular free zinc changes and found increasing expression of $z n t \mathrm{~A}$ in a zinc-dependent manner.

We also observed the increased expression of $z n t \mathrm{~A}$ in the presence of zinc at high concentration (Fig. 3) which correlated with high level of intracellular zinc in bacterial cells (Table 2). In addition, Wang et al. (2012) also observed prolonged accumulation of zinc in zntA mutant E. coli and they proposed $z i t \mathrm{~B}$ as constitutive first-line defense against toxic zinc influx and the upregulation of zntA is to lower the zinc concentration.

In our study, we observed constitutive expression of $z n t \mathrm{~A}$ even during normal growth conditions in all the strains of E. coli from sewage sample excepting the K-12 type culture. Hence we propose that the presence of zinc in the environmental niche, from which the strains are collected, would have 'trained' the zntA gene to express constitutively due to continuous exposure to zinc at least in less toxic levels (1.038 mg/L; Table 1). Further analysis of genes like $z n t \mathrm{R}$, the transcription factor which is known to be activated by zinc and which regulates znt $\mathrm{A}$ is expected to provide additional evidences towards the aforesaid proposal.

Based on our study we conclude (1) zntA is a constitutively expressing gene playing major role in zinc translocation in environmental strains of E. coli; (2) higher intracellular accumulation due to zinc shock in growth 
Table 2 Translocation of $\mathrm{Zn}$ and $\mathrm{Pb}$ by $E$. coli $\mathrm{SBVP1}$

\begin{tabular}{llll}
\hline Media supplement & $\begin{array}{l}\text { Heavy metal } \\
\text { analyzed }\end{array}$ & $\begin{array}{l}\text { Concentration in } \\
\text { media }(m M)\end{array}$ & $\begin{array}{l}\text { Concentration in cell pellet after 5 days of } \\
\text { E. coli growth }(\mathrm{mM})\end{array}$ \\
\hline $\mathrm{ZnSO}$ & $\mathrm{Zn}$ & 3.5 & 1.039 \\
$\mathrm{~Pb}\left(\mathrm{CH}_{3} \mathrm{COO}\right)_{2}$ & $\mathrm{~Pb}$ & 4.0 & 0.038 \\
$\mathrm{ZnSO}_{4}+\mathrm{Pb}\left(\mathrm{CH}_{3} \mathrm{COO}\right)_{2}$ & $\mathrm{Zn}$ & 3.5 & 0.308 \\
$\mathrm{ZnSO}_{4}+\mathrm{Pb}\left(\mathrm{CH}_{3} \mathrm{COO}\right)_{2}$ & $\mathrm{~Pb}$ & 4.0 & 0.140 \\
\hline
\end{tabular}

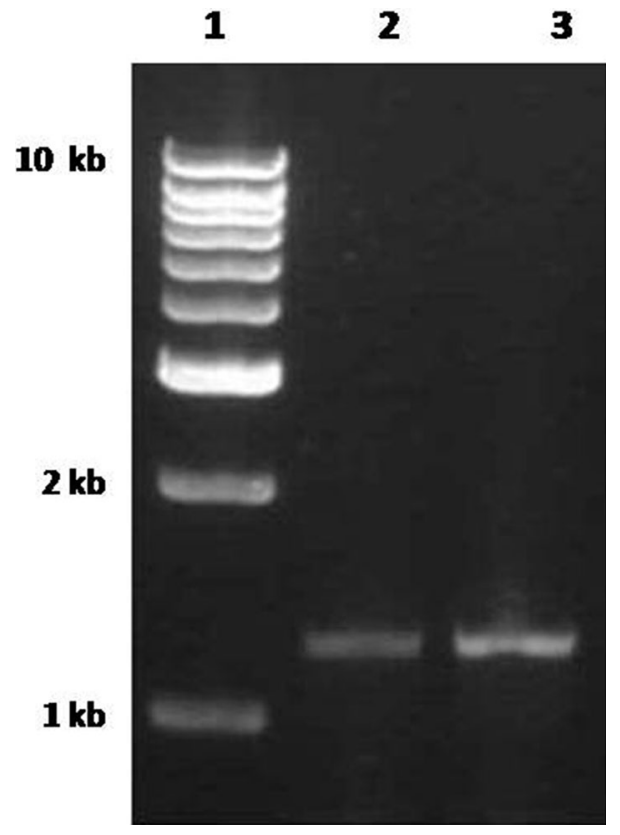

Fig. 3 RT-PCR analysis of $z$ tA gene expression in E. coli (SBVP1) cultured in media containing $\mathrm{ZnSO}_{4}$. Lanes 1 DNA marker, 2 E. coli SBVP1 grown without any heavy metal in media, 3 E. coli SBVP1 grown in media with $\mathrm{ZnSO}_{4}$

environment is controlled by the presence of $\mathrm{Pb}$ in the same environment; (3) zinc-induced zntA gene plays additional role in translocating $\mathrm{Pb}$, intracellularly.

Acknowledgements The authors gratefully acknowledge the support offered by the management, VIT University, Vellore, India, in performing this research work.

\section{Compliance with ethical standards}

Conflict of interest The authors declare that there is no conflict of interests.

Open Access This article is distributed under the terms of the Creative Commons Attribution 4.0 International License (http:// creativecommons.org/licenses/by/4.0/), which permits unrestricted use, distribution, and reproduction in any medium, provided you give appropriate credit to the original author(s) and the source, provide a link to the Creative Commons license, and indicate if changes were made.

\section{References}

Blencowe DK, Morby AP (2003) Zn(II) metabolism in prokaryotes. FEMS Microbiol Rev 27:291-311

Grass G, Fan B, Rosen BP, Franke S, Nies DH, Rensing C (2001) Zit $\mathrm{B}$ (YbgR), a member of the cation diffusion facilitator family, is an additional zinc transporter in Escherichia coli. J Bacteriol 183:4664-4667

Grass G, Otto M, Fricke B, Haney CJ, Rensing C, Nies DH, Munkelt D (2005) FieF (YiiP) from Escherichia coli mediates decreased cellular accumulation of iron and relieves iron stress. Arch Microbiol 183:9-18

Guven DE, Akinci G (2011) Comparison of acid digestion techniques to determine heavy metals in sediment and soil samples. Gazi Univ J Sci 24:29-34

Hantke K (2001) Bacterial zinc transporters and regulators. Biometals 14:239-249

Hantke K (2005) Bacterial zinc uptake and regulators. Curr Opin Microbiol 8:196-202

Ji G, Silver S (1995) Bacterial resistance mechanisms for heavy metals of environmental concern. J Ind Microbiol 14:61-75

Lee SM, Grass G, Haney CJ, Fan B, Rosen BP, Anton A, Nies DH, Rensing C (2002) Functional analysis of the Escherichia coli zinc transporter ZitB. FEMS Microbiol Lett 215:273-278

Nies DH (1992) Resistance to cadmium, cobalt, zinc, and nickel in microbes. Plasmid 27:17-28

Nies DH (1999) Microbial heavy-metal resistance. Appl Microbiol Biotechnol 51:730-750

Outten CE, Outten FW, O'Halloran TV (1999) DNA distortion mechanism for transcriptional activation by $\mathrm{ZntR}$, a $\mathrm{Zn}$ (II)responsive MerR homologue in Escherichia coli. Biol Chem 274:37517-37524

Rensing C, Mitra B, Rosen BP (1997) The zntA gene of Escherichia coli encodes a Zn(II)-translocating P-type ATPase. Proc Natl Acad Sci USA 94:14326-14331

Rosen BP (1996) Bacterial resistance to heavy metals and mettaloids. J Biol Inorg Chem 1:273-277

Silver S (1996) Bacterial resistances to toxic metal ions-a review. Gene 179:9-19

Wang D, Hosteen O, Fierke CA (2012) ZntR-mediated transcription of zntA responds to nanomolar intracellular free zinc. J Inorg Biochem 111:173-181

Wei Y, Fu D (2005) Selective metal binding to a membraneembedded aspartate in the Escherichia coli metal transporter YiiP (FieF). J Biol Chem 280:33716-33724 